\title{
The Influence of CEO's Demographic Characteristics on Tax Aggressiveness in Family Firm
}

\author{
Dwi Astutik ${ }^{1}$, Lintang Venusita ${ }^{2^{\star}}$ \\ 1,2 Department of Accounting, State University of Surabaya \\ Jl. Lidah Wetan, Surabaya 60213, Indonesia \\ Corresponding author; Email: 1dwiast0610@gmail.com, ${ }^{2 *}$ lvenusita@gmail.com
}

\begin{abstract}
This research aims to analyze how the educational background, tenure, and gender of Chief Executive Officer (CEO) affect tax aggressiveness in a family firm. Independent variables comprise the educational background, tenure, and gender of CEO while tax aggressiveness plays as dependent variable. In addition to those three parameters, the controlled variable also includes leverage and profitability. Population and sample of this research were taken from family firms registered in the Indonesian Stock Exchange during 2013 - 2016. With the purposive sampling, the number of total samples and sampling units in this research are 42 and 168, respectively. Furthermore, documentation techniques manifested in financial statement and annual report are used as data collection method where panel data regression with a fixed effect model is employed for statistical analysis. The present results demonstrate that the educational background and profitability significantly give a negative effect on the tax aggressiveness whereas the tenure and leverage considerably contribute to a positive consequence in the tax aggressiveness. Interestingly, it is shown that the gender factor does not substantially influence the tax aggressiveness.
\end{abstract}

Keywords: Family firm; tax aggressiveness; CEO education background; CEO tenure; CEO gender.

\section{INTRODUCTION}

The companies in the world mostly are familyowned companies,including Indonesia. [29] survey results mentioned that $60 \%$ of listed companies in Southeast Asia are family companies. The survey also revealed that more than $95 \%$ of businesses in Indonesia are family businesses. According to [34], the criterias used to define a family business include: percentage ownership, control of voting rights, strength of strategic direction, involvement of multiple generations, active management of family members, etc.

The presence of family members in the management structure can reduce agency problems in the company. The agency problem due to ownership separation arises when managers take some hidden actions. One of the actions of managers that harm shareholders is the act of tax aggressiveness, even though on the other hand there are advantages such as lower tax. Tax aggressiveness is often done by companies including family companies. [32] research on manufacturing companies listed on the IDX, proves that family companies are more aggressive concerning taxes than non-family companies. It occurs because the company think about a greater advantage than the risk of costs that may occur.

Tax aggressiveness has become an increasingly common feature for companies in the world as an effort to reduce the tax burden as low as possible [23]. For companies, taxes will reduce profits because it becomes one of the burdens that must be abided by the company, so the company will try to minimize the tax burden as efficiently as possible. Efforts made in tax savings direct management to act aggressively towards taxes. According to [15], aggressive tax action is the act of manipulating taxable income or lower fiscal profit through tax planning that can be classified as tax evasion or not.

Tax planning is one of the strategies in the company to increase profits and corporate value. This strategy will achieve its objectives when all components in the company support it. The decision of strategy selection is made by the company's executive manager, especially the CEO. CEO as the highest executive in managerial rank has a very important role, one of which is as the decision maker. As a decision maker, Every CEO has different behaviors, such as avoiding risk, taking risk, or being neutral towards risk. This behavior will affect the strategy chosen by the CEO.

Upper echelons theory discovered by [19] explains that managers can influence the creation of corporate values through their management style and personal abilities. This theory shows that the more complex a decision, such as strategy size, the more important personal characteristics of decision makers such as age, tenure and special expertise [3]. 
This theory explains that company results, strategy choices and performance levels are partially predicted from the background characteristics of managers [19]. This shows that decisions made by managers, especially CEOs, will affect the company's strategy. Tax planning as one of the company's strategies will be influenced by the characteristics of CEO of the company. Therefore, the characteristics of the CEO will affect the level of tax aggressiveness of a company. Previous research found that CEO characteristics which consisting of tenure [17], level of education and specialization [3] influence tax planning, [27] study, proves that male executives are bolder take the risk of tax avoidance compared to female executives. Based on this research, several factors that influence the level of tax aggressiveness are derived from the characteristics of the CEO consisting of educational background, tenure, and gender of the CEO.

[3], explained that CEOs who are graduates from the fields of finance and accounting have a theoretical basis that can increase the capacity of financial situation analysis and corporate taxation. This kind of knowledges can help the CEO in making financial decisions. The basic theory of finance and taxation obtained during education will be useful for the CEO in planning the most appropriate tax strategy. In line with that, the research of [33] stated that the level of education will have a positive effect on the level of taxpayer compliance. This shows that the higher the level of education, the more will be obedient to taxes, and minimize the tax aggressiveness.

Another factor influencing tax aggressiveness is the CEO's tenure. According to [28], the Upper echelons theory explained that when tenure increases, the CEO becomes more confident on taking more challenges in his financial decisions. A longserving $\mathrm{CEO}$ will be more courageous in taking risks because he already has enough experiences in decisions making. Therefore the CEO's tenure will have a positive effect on risk taking (D. [8]. In line with this, the research of [16] proved that the tenure of CEO has an effect on tax planning. The shortertenured CEOs tend to more careful in doing tax planning, on the other hand, the longer-tenured CEOs are more courageous in taking risks in tax reporting. It is also supported by [10] which explains that CEO characteristics such as CEO age, CEO gender, and CEO news have a positive effect on CEO publicity, while tenure has a negative impact on CEO publicity and CEO publicity has a negative impact on corporate tax avoidance. This shows that CEOs who have high publicity will minimize tax avoidance. New CEOs tend to avoid tax aggressiveness activities because of more public attention that they receive.
Another CEO characteristic that affects tax aggressiveness is gender. The act of tax aggressiveness is related to risk taking. Men and women have their own preferences for risk. Previous research explains that women avoid risk more than men in decision making [7]. Especially when making financial decisions, women avoid risk more than their male counterparts [5]. Female executives might choose to reduce corporate risk to a level that suits their preferences when they become CEO [13]. Female CEOs tend to avoid risk by making low-risk company decisions. Different research conducted by [14] proved that female CEOs do not avoid risks compared to male CEOs. The research showed that gender can influence choices in making decisions especially in dealing with risks, both in taking risks by managing them, being neutral toward risks, or avoiding risks. [22], explained that by increasing the presence of women councilors will reduce the level of tax aggressiveness. This research showed that women tend to avoid tax aggressiveness, due to minimizing the possibility of spending a larger amount. In line with this, [27] research proved that male executives are more willing to take the risk of tax avoidance. Unlike those two studies, [10] research proved that male and senior CEOs are active in reporting coverage, otherwise new CEOs who are determined to receive more public attention and publicity has a negative effect on corporate tax avoidance. This research proved indirectly that male CEOs and newly appointed CEOs may avoid tax avoidance. Their every action will get the spotlight more quickly from public, so they must be more careful in taking decisions because it will affect their image.

Tax aggressiveness is not only influenced by the characteristics of the CEO (educational background, tenure, and gender), but is also influenced by other factors such as leverage [30] and profitability [15]. According to [30], leverage is negatively related to the Corporate Effective Tax Rate (ETR). This shows that the higher the leverage of the company, the lower the value of ETR, which means the higher level of tax aggressiveness carried out. According to [15] ROA has a positive effect on tax shelter activities. Therefore leverage and profitability become control variables.

Based on the background that has been outlined, the problem will be discussed in this research is whether the tenure, educational background and gender of the CEO affect the tax aggressiveness in the family company. Hence, the research objective is to prove the effect of CEO's tenure, educational background and gender on tax aggressiveness in family companies, by adding leverage and profitability as control variables. 


\section{Upper echelons theory}

Upper echelons theory emphasizes the role of managers in creating corporate value with their management style and personal abilities [3]. The personal ability of manager will have an impact on the company outcomes-strategic choices taken by top manager. The theory explained about the concept that company outcomes-strategic choices and performance levels-are partially predicted by managerial background [19]. Both company outcomesstrategic choices and effectiveness are considered as a reflection of the values and cognitive basis of the authorities in the company which is the top managers. Decision making is done by top managers, especially CEOs. The characteristics of the manager affect the decision making that will affect the choice of strategy taken. Due to limitation on the standard psychological dimensions (values and cognitive basis), the upper echelon perspective observes only on the tangible background of managers such as age, education and others.

Upper echelons theory explains that the characteristics of top managers consisting of psychological and observable dimensions are related to the choice of corporate strategy. This shows that the characteristics of managers influence the choice of corporate strategy which will have an impact on company performance. [18] explained that the basic logic of Upper echelons theory is that executives make decisions on the basis of their personal construal in the situation at hand. So the essence of this theory explains the choice of company strategy which is influenced by the characteristics of top managers, where the strategy chosen will have an impact on company performance.

\section{Relationship between CEO Education Back- ground and Tax Aggressiveness}

According to [20], education is related with gaining knowledge and accumulating facts. Furthermoreeducation is also related with the development of certain desired personal qualities, such as creativity, autonomy, critical thinking, due to development of knowledgeable and balanced person. According to Richey in [4], education is a broader process than what happens in schools, education is an important social activity that continues to exist in society. According to [4], the educational goals found, thought, and developed by Benyamin S. Bloom are categorized into 3 namely: cognitive ability, which is associated with awareness or recognition of knowledge and development of intellectual abilities and skills; affective ability, which explain changes in interests, behavior, and values; and psychomotor ability, which is the skillsof manipulation and supervision.
Education is one of the important needs that must be fulfilled, it is also applied for CEO. According to [6], the education of CEOs potentially increases their knowledge, perspective and the ability to understand abstract techniques and concepts. Higher education can be an indication of their intelligence and the ability to sustain in challenging intellectual activities. The CEO education level shows cognitive ability - the ability related to knowledge - as well as their intellectual ability. CEO education level has a positive influence on risk taking [14]. The higher the level of CEO education, the more risk-taking it will be. The ability to make decisions will be better because of the higher cognitive ability.

Education contributes to the construction of values, knowledge, skills, and cognitive preferences, which influence executive managerial decisions [19]. Educational background is a factor that will influence in making decisions, especially from specialization in the particular field of science. [3], explained that CEOs who earned degree on finance and accounting, have a theoretical basis that can increase the capacity of financial situation analysis and corporate taxation. The knowledge can help the CEO in making financial decisions. The knowledge gained can be the basis for making decisions and determining the right strategy, one of which is tax aggressiveness.

[33], proves that the level of education will have a positive effect on the level of taxpayer compliance. This means that the higher a person's education, the more they will comply with taxes. With the level of education that the CEO will be more willing to take risks but still obey the law. Fields of science taken in education will be useful as a basis for taking decisions. Therefore the level of education and science of the CEO can influence their actions in tax aggressiveness. Based on the explanation, the hypotheses that can be formulated are:

$\mathrm{H}_{1}$ : CEO educational background influences tax aggressiveness.

\section{Relationship between CEO tenure to tax aggressiveness}

The term of office of the CEO can be defined how long a CEO occupies his position as CEO in the company he leads. According to [28], in Upper echelons theory it is explained that tenure increases, the CEO becomes more confident and will take on more challenges in his financial decisions. A longserving CEO will be more courageous in taking risks because he already has enough experience in decision making. Knowledge of the condition of the company it manages so far is a guideline in the decisions that will be taken. One of the decisions taken by the CEO is the company's strategy. 
The CEO has an important role in strategic change and the CEO's tenure can be an important predictor in strategic change. [35] explain that new CEOs, with new views and perspectives, are more likely to initiate change and with increasing years the motivation to try new alternatives gradually decreases. So that strategic changes are less likely when the CEO has long served in the company.

The new CEO will be more careful, so that in tax planning his actions are less aggressive. This shows that the CEO's tenure will influence it in the selection of tax planning strategies. In line with research by [17], which stated that the CEO in his new term would be more careful in doing aggressive tax reporting. Based on the theory that has been explained the hypothesis that can be formulated, namely:

$\mathrm{H}_{2}$ : $\mathrm{CEO}$ tenure has an effect on tax aggressiveness.

\section{Relationship between the CEO's Sex and Tax Aggressiveness}

Genders are categorized as male and female. In terms of leadership, the difference between the two is communal and agentic [12]. According to [12] women are associated with communal quality. The communal in question includes being a person who is affectionate, helpful, friendly, kind, and sympathetic, and sensitive interpersonal, gentle, and speaks softly, while men are associated with agentic quality. Agentic in this case includes being very aggressive, ambitious, dominant, confident, and strong, as well as independent and individualistic. Differences in the characteristics of men and women will affect their behavior, one of which is risk behavior.

Men and women have different risk preferences. [14] research proves that female CEOs do not avoid risks compared to their male counterparts. However, this study is not in line with the study of [7] and [13] which explains that women tend to avoid risks in making decisions, compared to men. According to [21], women are more ethical and riskaverse. A stronger ethical character than women leaders embodies a stronger ethical leadership so that the work atmosphere is more ethical. This ethical work atmosphere encourages honesty in financial reporting, impedes earnings management, and has the potential to foster more conservative accounting. In the research of [21] Women are more conservative in reporting earnings, because their behavior is more ethical and risk-averse. These ethical behaviors minimize the existence of fraudulent actions (fraud) that can be committed by leaders or managers.

CEOs who dare to take risks will be more courageous in carrying out tax aggressiveness.
Therefore the CEO's gender will influence his actions to carry out tax aggressiveness. Research conducted by [22], proves that increasing the presence of female councilors will reduce the level of tax aggressiveness. This research shows that women tend to avoid tax aggressiveness, this is in order to avoid the greater amount of costs. In line with [27] research which proves that male executives are more willing to take the risk of tax avoidance. From both of these studies indicate that one of the characteristics of the CEO that is gender can affect tax aggressiveness in the form of tax avoidance. Based on the theory that has been explained the hypothesis that can be formulated, namely:

$\mathrm{H}_{3}$ : CEO's gender influences tax aggressiveness

\section{RESEARCH METHOD}

\section{Research Sample}

The research sample is family companies that went public in 2013-2016. A publicly listed company is called a family company if the founder or acquirer has $25 \%$ rights to the company through investment, at least one representative or family member is involved in the management of the company [29] and family members are reported as "ultimate ownership" [2]. Companies that are classified in a family company have 2 criteria, namely individuals I families, or companies that do not go public are controlling shareholders (referring to Bank Indonesia Regulation Number 12/23/PBI/2010), whether they are founders or not [2], and family members hold key management positions in both the board of commissioners and the board of directors [9], [25], [34].

The research sample was taken using purposive sampling method which must meet the criteria including companies that experienced profits or no losses during 2013-2016, companies with CETR values of 0 to 1 , companies have complete information about educational background, tenure, and gender of the CEO . Based on the selected sampling method, a total sample of 42 samples was obtained with 168 sample units.

\section{Operational Variables and Definitions}

\section{Dependent Variable}

The dependent variable used in the study is tax aggressiveness. Tax aggressiveness is an act of manipulating lower taxable income or fiscal profit through tax planning that can be classified as tax evasion or not [15]. Referring [1] and [11], the proxy of tax aggressiveness in the research conducted is 
Cash Effective Tax Rate (CETR). According to [11] formula for calculating the Cash Effective Tax Rate (CASH_ETR), namely:

$$
\text { CASH_ETR }=\frac{\text { Tax payment }}{\text { Profit before tax }}
$$

\section{Independent Variable}

The independent variables in the study are educational background, tenure and gender of the CEO. Information or data from the independent variables used is obtained from the annual report of the profile section of the CEO or president director. CEO education background is measured by using Dummy referring to [3] research, giving dummy, namely for CEOs whose educational background comes from finance, accounting, and tax with S2 education level symbolized by a value of 1 , while for CEOs whose educational background others are denoted by a value of 0 . Referring to previous research [3], [26], [35] the CEO's tenure is proxied by the number of years the CEO served as CEO in the company. CEO gender measurement proxy that uses dummy where the value of 1 for male CEOs, and 0 for female CEOs [10]

\section{Control variable}

The control variables used in the study are leverage and profitability. Leverage can be interpreted as the company's ability to manage debt to finance its investment, meaning that the company's assets are financed with debt. According to [24], leverage can be calculated using the formula:

$$
\text { Lev }=\frac{\text { Total Liability }}{\text { Total Asset }}
$$

Profitability is used as a measure of a company's ability to obtain profits. One of the proxies in finding the probability of a company is by using the ROA (Return on Asset) ratio, which is a calculation to adhere to the level of return obtained from the use of assets. According to [31] the formula for calculating ROA, namely:

$$
\text { ROA }=\frac{\text { Net Profit }}{\text { Total Asset }}
$$

\section{Data collection}

The data used in this research is a type of quantitative data sourced from secondary data. Data collection for research conducted using documentation techniques. The data in the study came from annual reports and financial statements of family companies that went public in 2013-2017 which can be downloaded at www.idx.co.id.

\section{Data analysis technique}

Data analysis used in the research conducted was a panel data regresis analysis model. The determination of the panel data estimation model between the common efffect model, the fixed effect model, and the random effect model is performed by the chow/likelihood test, the haustman test, and the multiple lagrange test. After testing the estimation model, a classic assumption test is performed which consists of the test of Heteroskedastisistas, autocorrelation, multicollinearity, and normality. Hypothesis testing is done by making the regression model equation as follows:

$$
\begin{gathered}
A P_{i t}=\alpha_{i t}+\beta_{1} L B P_{i t}+\beta_{2} T_{e n}+\beta_{3} J K_{i t}+\beta_{4} L_{e v} v_{i t} \\
+\beta_{5} R O A_{i t}+\varepsilon_{i t}
\end{gathered}
$$

Information:

AP = Tax Aggressiveness is measured by CETR

a $=$ Constant

$B=$ Regression Coefficient

LBP $=$ CEO Education Background

Ten $=$ CEO Term

$\mathrm{JK}=$ Gender CEO

Lev = Leverage

ROA $=$ Profitability

$\varepsilon \quad=$ Error

i $\quad=1,2, \ldots .$, (corporate entity)

$\mathrm{t} \quad=1,2, \ldots .$, (Year)

Hypothesis testing is done by testing the feasibility of a regression model using the coefficient of determination (R2), simultaneous test, and partial test. Simultaneous test is conducted to determine the effect of the independent variables on the dependent variable together. This test is done by looking at the probability value of the F-Statistic. Partial test is carried out to test the effect of individual independent variables on the dependent variable. This test is done by looking at the probability value of the t-statistic.

\section{RESULTS AND DISCUSSION}

\section{Research Result}

The purpose of this research is to prove the influence of educational background, tenure, and gender of the CEO on tax aggressiveness by including leverage and profitability as control variables. The object of research is the family company that has been going public with the research period of 2013-2016. The research sample used by the puposive sampling method was 42 samples with 168 units of sample units. The research data of 168 data which is the number of sample units. 
Statistical description results show an average value of CETR of 0.345858 and a standard deviation of 0.4053 . The largest value of CETR is 3.5776 and the smallest value is 0.0016 , while the median of CETR is 0.2627 . The average value of tenure is 12.0676 with a standard deviation of 0.3177 , while the median value is 7 . The largest value is 46 and the smallest value is 0.5 . Educational background and gender are dummy variables, therefore these variables have the largest value of 1 and the smallest value of 0 . The average value of educational background is 0.2560 with a standard deviation of 0.4377 . The average value of gender is 0.8869 and the standard deviation is 0.3177 .

The average value of leverage is 0.5245 and the standard deviation is 0.2048 . The biggest value is 0.9212 and the smallest value is 0.1383 . The median value of leverage is 0.5115 . ROA which is a proxy of profitability has an average value of 0.0583 with a standard deviation of 1.7784 , while the median value is 0.0490 . The biggest value is 0.3024 and the smallest value is 0.0018 .

Based on the Chow Test (Likelihood test) and the Haustman test it can be concluded that in the research conducted the fixed effect model is the best model in estimating the regression model. In the Fixed effect model to choose one of the three types of estimation methods that are appropriate can be done by looking at the structure of the variancecovariance. Based on the results of heteroscedasticity test and autocorrelation test indicate that the residual variance-covariance structure is assumed to occur heterocedasticity but is free from cross-section correlation. Therefore the estimation method that is suitable for fixed effect models is the estimation of GLS (General Least Square) or WLS (Weight Least Square) by weighting the weight cross-section.

GLS (General Least Square) or WLS (Weight Least Square) by weighting cross-section weighting becomes the estimation method used, then it is free from heterokedasticity test and auto correlation test, so it only needs normality test and multicollinearity test in the assumption test. Based on the test, it is known that the residual data are normally distributed and there is no multicollinearity between independent variables.

Based on testing the regression equation hypothesis that can be formulated, namely:

$$
\begin{aligned}
A P=-0,165012 & -0,238167 L B P_{i t}+0,013044 \text { Ten }_{i t} \\
& +0,017301 J_{i t}+0,914679 \text { Lev }_{i t} \\
& -1,384687 \text { ROA }_{i t}+\varepsilon_{i t}
\end{aligned}
$$

Based on hypothesis testing, the R-Squared value is 0.808436 or $80.8436 \%$. These results indicate the independent variables in the form of educational background, tenure, and gender as well as leverage and profitability as a control variable capable of explaining the dependent variable namely tax aggressiveness of $80.84 \%$ and $19.16 \%$ explained by other variables outside the study.

The results of the simultaneous test (statistical test F) known $p$ value or probability value of the Fstatistic of 0.0000 which is below the significant level of 0.05 , this indicates if the variable educational background CEO, CEO tenure, CEO sex, leverage and profitability simultaneously or jointly affect the aggressiveness

The partial test shows the t-statistic probability value of educational background of 0.0000 which is below the significant level (0.05), meaning that it rejects $\mathrm{H} 0$ and accepts $\mathrm{H} 1$. The coefficient value of educational background is -0.238167 where the coefficient value is negative, meaning that the educational background has a negative effect on the level of corporate tax aggressiveness.

The probability value of tenure is 0.0002 which is below the significant level (0.05), which means rejecting $\mathrm{H} 0$ and accepting $\mathrm{H} 1$. The tenure variable has a coefficient value of 0.013044 where the coefficient value is positive, meaning that the term of office has a positive effect on the level of corporate tax aggressiveness.

The probability value of the sex is 0.6392 which is above the significant level (0.05), which means reject $\mathrm{H} 1$ and accept $\mathrm{H} 0$. These results indicate if there is no gender effect on the level of corporate tax aggressiveness.

The probability value of leverage and profitability as control variables is 0.0000 . Both have a probability value of 0.0000 which means that it is below the significant level set at 0.05 , which means rejecting $\mathrm{HO}$ and accepting $\mathrm{H} 1$. The test results show if both control variables both leverage and profitability affect the dependent variable.

The coefficient of leverage shows a value of 0.914679 where the coefficient is positive, meaning that leverage has a positive effect on tax aggressiveness. The coefficient of profitability shows a value of -1.384687 where the coefficient is negative, meaning that profitability has a negative effect on tax aggressiveness.

The test results indicate if the variables of educational background, tenure, leverage and profitability are significant in corporate tax aggressiveness, but on the other hand gender variables are not significant in corporate tax aggressiveness.

\section{Discussion}

\section{The influence of CEO education background on tax aggressiveness}

The first hypothesis states that CEO education background influences tax aggressiveness. Hypothesis test results prove if the first hypothesis is 
accepted, it means that there is an influence of CEO education background on corporate tax aggressiveness. Based on the Upper Echelons Theory explains that education contributes to creating one's values, knowledge, skills and cognitive preferences, which influence executive managerial decisions [19]. CEO who is a graduate of the fields of finance and accounting has a theoretical basis that can increase the capacity of financial situation analysis and corporate taxation [3]. The education obtained contributes well to understanding taxation.

The test results prove that negative educational background is significant in tax aggressiveness. These results indicate that if the CEO with an educational background in finance, accounting, and taxation with a higher level of education is less tax aggressive than the CEO with an educational background in other fields. The results of the first hypothesis are in line with [3] research, which proves that the level of education and special expertise of the CEO influences tax planning. Research is also relevant to [33] which proves that the level of education will positively influence the level of taxpayer compliance. The research explains that the higher level of education a person will make more compliant with taxes, so less tax aggressiveness.

\section{Effect of CEO tenure on Tax Aggressiveness}

The second hypothesis states that the CEO's tenure has an effect on tax aggressiveness. Hypothesis test results prove if the hypothesis is accepted. The test results show the CEO tenure has a positive effect on corporate tax aggressiveness. This indicates that the longer the CEO's position in the company, the higher the level of tax aggressiveness. Long-serving CEOs have the ability, knowledge, and experience that can influence decision making. The knowledge and experience that has been obtained provides the ability to analyze company conditions.

The results of the second hypothesis testing are relevant to the research of [17], which proves that CEOs in his new term will be more careful in doing aggressive tax reporting. This means that the more the CEO has served in the company, he will be cautious or less aggressive in acting on taxes. Conversely CEOs who have long served will be more aggressive towards taxes.

\section{Effect of CEO sex on tax aggressiveness}

The third hypothesis states that the gender of the CEO influences the tax aggressiveness. Based on the results of testing that has been done the hypothesis is rejected, meaning that there is no influence of the CEO's gender on the level of corporate tax aggressiveness. The test results indicate if the CEO's gender does not influence it in making decisions. Men and women have no difference in their behavior with respect to taxes. Both have different risk preferences but do not make them behave differently in tax aggressive actions. Tax aggressiveness is not influenced by the CEO's gender but is influenced by other things, especially educational background and tenure which are included in the research variables.

This result is relevant to the research of [17], which proves that gender proxied by men and women has no effect on tax payments. This means that there is no difference between male and female behavior in tax payments, so there is no difference in tax aggressiveness

\section{CONCLUSION}

\section{Conclusion}

Research results based on the influences of three pivotal independent variables, i.e. educational background, tenure, and gender of CEO on tax aggressiveness in family companies indicate that CEO's educational background has a negative effect on the tax aggressiveness. This means that CEOs with an educational background in finance, accounting, and taxation with a higher education degree will reduce aggressive tax action. In particular, CEOs who have higher educational background will be more aware of tax payments so that they are not belligerent towards taxes.

Unlike the finding on the CEO's educational background, the CEO tenure has a positive effect on the tax aggressiveness. This signifies that the longer the CEO has served in a company, the higher the aggressive tax action is. Moreover, new CEOs in the company will be more cautious in their actions, which in turn will make the aggressive tax action lower. Interestingly, the gender of CEO does not affect the tax aggressiveness. This indicates that the tax aggressiveness of male and female CEOs does not have a significant difference. Both male and female CEOs have no difference in aggressive actions against taxes.

Similarly, leverage has a positive effect on the tax aggressiveness. It is shown that the tax aggressiveness is high when corporate leverage is high. Conversely, profitability has a negative consequence on corporate tax aggressiveness. From this finding, it is demonstrated that the higher the profitability, the less aggressive the company is with taxes, and vice versa. Furthermore, if the profitability is low, then the company will try to reduce company burden: one of which is to reduce the tax burden as low as possible by carrying out the tax aggressiveness. 


\section{Suggestion}

The present research does not consider the following crucial issues which bring the impetus for further investigation:

1. Use and or combine several other proxies for the tax aggressiveness variable. This is due to limitations in the CETR proxy.

2. The use of objects in other countries where the gender of the CEO of the company between men and women is balanced, due to the male domination of corporate CEOs in Indonesia.

3. Adding other CEO characteristic variables both internal and external characteristics that can affect tax aggressiveness.

\section{REFERENCES}

[1] Adhikari, A., Derashid, C., and Zhang, H. (2006). Public policy, political connections , and effective tax rates: Longitudinal evidence from Malaysia. 25, 574-595. https://doi.org/10.1016/ j.jaccpubpol.2006.07.001

[2] Aktas, N., Centineo, S., and Croci, E. (2016). Value of Control in Family Firms: Evidence from Mergers and Acquisitions. Multinational Finance Journal, 20(2), 85-126.

[3] Aliani, K. (2014). CEO characteristics and corporate tax planning evidence from US companies Khaoula Aliani. International Journal Managerial and Financial Accounting, 6(1).

[4] Anwar, M., Filsafat Pendidikan, Kencana., Jakarta, 2015.

[5] Belot, F., and Serve, S. (2017). Earnings Quality in Private SMEs : Do CEO Demographics Matter? Journal of Small Business Management, 00(00), 1-22.

[6] Bhagat, S., Bolton, B., and Subramanian, A. (2010). CEO Education, CEO Turnover, and Firm Performance CEO Education, CEO Turnover, and Firm Performance.

[7] Charness, G., and Gneezy, U. (2012). Journal of Economic Behavior and Organization Strong Evidence for Gender Differences in Risk Taking. Journal of Economic Behavior and Organization, 83(1), 50-58.

[8] Chen, D., and Zheng, Y. (2013). CEO Tenure and Risk-Taking. SSRN Electronic Journal.

[9] Chen, S., Chen, X., and Shevlin, T. (2010). Are Family Firms more Tax Aggressive than Nonfamily Firms? Journal of Financial Economics, 1(91), 41-61.

[10] Duan, T., and Zhang, J. Z. (2018). The burden of attention: CEO publicity and tax avoidance. Journal of Business Research, 87, 90-101.

[11] Dunbar, A., Higgins, D. M., Phillips, J. D., and Plesko, G. A. (2010). What Do Measure of Tax
Aggressiveness Measure? National Tax Association Proceedings, 103.

[12] Eagly, A. H., and Johannesen-schmidt, M. C. (2001). The Leadership Styles of Women and Men, 57(4), 781-797.

[13] Faccio, M., Marchica, M., and Mura, R. (2016). CEO Gender, Corporate Risk-Taking , and The Efficiency of Capital Allocation. Journal of Corporate Finance, 39, 193-209.

[14] Farag, H., and Mallin, C. (2016). The influence of CEO demographic characteristics on corporate risk-taking: evidence from Chinese IPOs. European Journal of Finance.

[15] Frank, M. M., J.Lynch, L., and Rego, S. O. (2009). Tax Reporting Aggressiveness and Its Relation to Aggressive Financial Reporting. The Accounting Review, 84(2), 467-496.

[16] Goldman, N. C., Powers, K., and Williams, B. M. (2017). How does CEO tenure affect corporate income tax planning and financial reporting decisions?

[17] Gunawan, H., and Melisa. (2017). The Relationship between Gender and Tax Payments. Journal of Apllied Accounting and Taxation, 2(2), 209-215.

[18] Hambrick, D. C. (2007). Upper Echelons Theory: An Update. Academy of Management Review, 32(2), 334-343.

[19] Hambrick, D. C., and A.Mason, P. (1984). Upper Echelons Theory The Organization as a Reflection of Its Top Managers. The Academy of Management Review, 9(2), 193-206.

[20] Hirst, P. H., Peters, R. S., and Gregory, I. (1972). The Logic of Education. Anaylitic Philosophy, 13(1).

[21] Ho, S. S. M., Li, A. Y., Tam, K., and Zhang, F. F. (2015). CEO Gender, Ethical Leadership, and Accounting Conservatism. Journal of Business Ethics, 127(2), 351-370.

[22] Lanis, G. R. G. T. R. (2016). Women on Board of Directors and Corporate Tax Aggressiveness in Australia: An Empirical Analysis. Accounting Research Journal, 29(3).

[23] Lanis, R., and Richardson, G. (2012). Corporate social responsibility and tax aggressiveness: a test of legitimacy theory. Accounting, Auditing and Accountability Journal, 26(1), 75-100.

[24] Liu, X., and Cao, S. (2007). Determinants of Corporate Effective Tax Rates : Evidence from Listed Companies in China. The Chinese Econmy, 40(6), 49-67.

[25] Martinez, A. L., and Ramalho, G. C. (2014). Family Firms and Tax Aggressiveness in Brazil Family Firms and Tax Aggressiveness in Brazil. Internationan Business Research, 7(3). 
[26] Nguyen, P., Miloud, T., and Zhao, R. (2017). CEO tenure and firm growth: A conditional analysis. Economics Bulletin, 37(4), 23012308.

[27] Novita, N. (2016). Executives Characters, Gender and Tax Avoidance: A Study on Manufacturing Companies in Indonesia. Advances in Economics, Business and Management Research, 15, 92-95.

[28] Orens, R., and Reheul, A. (2011). Do CEO Demographics Explain Cash Holdings in SMEs? HUB Research Papers Economics and Management.

[29] PwC. (2014). Survey Bisnis Keluarga 2014.

[30] Richardson, G., and Lanis, R. (2007). Determinants of the variability in corporate effective tax rates and tax reform: Evidence from Australia. Journal of Accounting and Public Poli$c y, 26,689-704$.
[31] Ross, S. A., Westerfield, R. W., Jordan, B. D., Liim, J., and Tan, R., Pengantar Keuangan Perusahaan, Salemba Empat., Jakarta, 2015.

[32] Sari, D. K., and Martani, D. (2010). Ownership Characeristics, Corporate Governance, and Tax Aggressiveness. The Third Accounting and The Second Doctoral Colloquium, 27-28.

[33] Sebhat, W., and Assfaw, A. M. (2019). Analysis of Tax Compliance and Its Determinants: Evidence from Kaffa, Bench Maji and Sheka Zones Category B Tax Payers, SNNPR, Ethiopia. Journal of Accounting Finance and Auditing Studies (JAFAS), 5(1), 32-58.

[34] Shanker, M. C., and Astrachan, J. H. (1996). Myths and Realities: Family Businesses' Contribution to the US Economy - A Framework for Assessing Family Business Statistics. Family Bussiness Review, 9(2), 107-123.

[35] Weng, D. H., and Lin, Z. J. (2012). Beyonds CEO Tenure: The Effect of CEO Newness on Strategic Changes. Journal of Management. 